\title{
The Crisis, the Humanities and Medical History
}

\author{
BILL LUCKIN*
}

\author{
Keywords: Credit Crunch; Economic Crisis; Coalition Government; \\ Humanities; Medical History; Postgraduate Students; University Cuts
}

Non-controversially, the full version of this article argues that the crisis in British higher education will impoverish teaching and research in the arts and humanities; cut even more deeply into these areas in the post-1992 sector; and threaten the integrity of every small sub-discipline, including the history of medicine. It traces links between the Thatcherite reforms of the 1980s and the near-privatisation of universities proposed by the Browne Report and partly adopted by the coalition. ${ }^{1}$ The article ends by arguing that it would be mistaken to expect any government-driven return to the status quo ante. New ideas and solutions must come from within. As economic and cultural landscapes are transformed, higher education will eventually be rebuilt, and the arts and social sciences, including medical history, reshaped in wholly unexpected ways. This will only happen, however, if a more highly politicised academic community forges its own strategies for recovery.

In common with every economically advanced nation traumatised by the credit crunch, and its euro-related repercussions, Britain will experience a protracted period of electoral and governmental instability. In due course, this may directly, and via greatly more complex routes, generate new research foci, new theoretical perspectives and new forms of ideological critique. Attempts to recover the comforting institutional and academic arrangements that prevailed between the 1960s and the mid-point of the Blairite era - the moment at which current policies first began to see the light of day - will fail.

Historians are bad at prediction. Sometimes, however, the immediate future becomes very nearly self-evident. Even closeted practitioners find it difficult to blunder into erroneous speculation. In the recent past, however, far too many academics have failed to react to the chill wind of change. Not a few, and particularly those working in elite Russell Group universities, have attempted to insulate themselves from massively significant policy debates. For them, intellectual freedom and autonomy - key watchwords of the 1960s and 1970s - have remained nostalgia-tinged half-realities in a system long since in thrall to senior management teams, cost accountants and governments

(C) Bill Luckin, 2011.

* Bill Luckin, Research Professor in Urban History, University of Bolton, Deane Road, Bolton BL3

5AB, UK. Email: billluckin@googlemail.com

\footnotetext{
1 'Securing a Sustainable Future for Higher Education', <http://www.independent.gov.uk/ browne-report $>$, accessed 3 December 2010; see also, the fine riposte by James Vernon, 'The End of the Public University in England', <http://www. reallyopenuniversity.wordpress.com/20/11/22/theend-of-the-public-university-in-england/>, accessed 3 December 2010.
} 


\section{Bill Luckin}

bewildered by the problem of how to sustain the funding of ever larger and increasingly expensive and complex public sector responsibilities. ${ }^{2}$

There had been numerous false alarms. Which teachers or researchers participated, without tongue in cheek, in Margaret Thatcher's and Sir Keith Joseph's 1980s request that historians and social scientists soberly assess the impact of departmental cuts of between eighteen and thirty per cent? ${ }^{3}$ Who bothered fully to decode the ideological and academic meanings of Sir Keith's determination to rename the Social Science Research Council the Economic and Social Research Council? His leader had denied the existence of 'society'. The Education Minister said that he wanted to see 'science' restricted to the laboratory. ${ }^{4}$ Ominous warnings! The anti-humanistic banner was raised and Oxford denied Mrs Thatcher an honorary degree. Her response can be all too readily recalled: 'If they do not wish to confer the honour, I am the last person who would wish to receive it'.

\section{Contextualising the Cuts}

Margaret Thatcher didn't much like 'intellectuals'. ${ }^{6}$ However, she resisted dictating who should go to university and what they should study when they got there. Now, confidently striding or tottering towards semi-privatisation, British higher education institutions are being incorporated by the state. The original version of this paper emphasised that the financial collapse of 2008 escalated public debt to levels that might have hiked unemployment rates far above those experienced in the 1930s. ${ }^{7}$ Different nations opted for different solutions. In Britain, the Coalition cut more deeply into the public sector than any government since the 1920s, and on a scale comparable to emergency measures in 'failing nations' such as Greece, Spain and (now, also) benighted Ireland. ${ }^{8}$ The higher education system found itself axed more ruthlessly than any other area, with the exception of welfare payments. ${ }^{9}$ But, as we shall see, the promise of near-privatisation also signalled the creation of a new, government-driven system of control. Rich material for theorists of the relationships between the contemporary state and instantaneous, globalised systems for the movement of capital and debt!

As large-scale reaction to the events of October 2010 - and the riots of 10 and 25 November- demonstrated, the assault on the universities, and particularly the changes to student funding and government support for teaching budgets angered large sections of the British public. The original version of this paper presented a bleak picture. Indeed,

\footnotetext{
${ }^{2}$ Rodney Lowe, The Welfare State in Britain since 1945, 3rd edn (Basingstoke: Palgrave Macmillan, 2005).

${ }^{3} \mathrm{H}$. Young, One of Us: A Biography of Margaret Thatcher (London: Macmillan, 1990), 414.

${ }^{4}$ B. Harrison, Finding A Role? The United Kingdom 1970-1990 (Oxford: Oxford University Press, 2010), 400.

${ }^{5}$ Young, op. cit. (note 3), 402.

${ }^{6}$ B. Harrison, 'Mrs Thatcher and the Intellectuals', Twentieth Century British History, 5, 2 (1994), 206-45.
}

\footnotetext{
${ }^{7}$ Ironically, the best concise account remains, Vince Cable, The Storm: The World Economic Crisis and What it Means, rev. edn (London: Atlantic, 2010)

${ }^{8}$ A. Blundell-Wisnall and P. Slovik, 'The EU Stress Test and Sovereign Debt Exposure' (Paris: OECD Financial Affairs Division, Working Papers on Finance and Private Pensions, no. 4, 2010), 8-11.

${ }^{9}$ The Guardian, 'Spending Review Axe Falls on the Poor', 21 October 2010, 1.
} 


\section{The Crisis, the Humanities and Medical History}

the author found himself castigated for undue pessimism and a failure to suggest strategies of resistance. The November riots constituted an activist response to those demands. At the same time, however, the attack on Millbank allowed the tabloids, and, in a much smoother style, the Prime Minister to regenerate 1960s-style stereotypes of students as coddled and disruptive hooligans. ${ }^{10}$

The Browne Report, and the government's response to it, proved more radical than this writer predicted. In terms of the role of central government, it proposed the abolition of the Higher Education Funding Council (HEFCE) and the Quality Assurance Agency (QAA) and the establishment of a new body which would be responsible for funding, maintaining standards, addressing student complaints, and persuading elite universities to provide larger numbers of places for those living in the poorer postcodes. ${ }^{11}$ Thus far, the furore over student fees has diverted public and governmental attention from all but the last of these tasks. ${ }^{12}$

When compared with the STEM subjects, the humanities and social sciences suffered traumatically. The acronym was coined by Lord Mandelson. ${ }^{13}$ It pointed to the perceived post-Blairite necessity of subsidising science, technology, engineering and mathematics places at the expense of disciplines thought to be marginal to economic recovery. The STEM agenda also demonstrated a high degree of inter-party consensus over higher education, although, as only a Martian would now fail to comprehend, the pre-election Liberal Democrats were at that time committed to quite different kinds of policies. ${ }^{14}$

\section{Marginalising History of Medicine?}

What will be the impact of the cuts on the history of medicine? First, humanities-based and social scientific areas of study, as currently constituted, will thrive or perish together. In an interdisciplinary universe, every body of knowledge and theory depends on and interacts with nearly every other. Second, the pool from which able students potentially interested in going on to postgraduate research, will be significantly reduced. Third, in cultural, class and economic terms, the reduced pool will gravitate

\footnotetext{
${ }^{10}$ No British tabloid devoted fewer than four highly visual pages to the 'riots'. Key emphasis was given to the student who threw a fire extinguisher from the lower roof of the Conservative Party Headquarters and who has now been charged with attempted murder. For David Cameron's interpretation of these events see 'Cameron "worried" by student riot', BBC Radio 4, Today, 11 November 2010. <http://news.bbc.co.uk/today/hi/today/ 9178000/9178687.stm/>, accessed 3 December 2010.

${ }^{11}$ Steve Smith, 'Where is the Mandate to Change the World of Higher Education?' Education Guardian Higher, 19 October 2010, 6. See also, Rebecca Attwood, 'Mega-Quango would Control Funding, Access, Quality and Student Issues', Times Higher Education, 14 October 2010, 8-9.

${ }^{12}$ However, the up-front nature of the new fees system, and the exceptionally generous pay-back
}

arrangements make it the most generous in the developed world. A fully qualified GP, earning over $£ 120,000$, will pay about $£ 120$ a month. If she loses her job, she will pay nothing. If she took a job for $£ 30,000$ she would pay $£ 68$ a month. Below $£ 21,000$ she would pay nothing. The fee rises are much less significant than the shrinkage of the higher education system as a whole and the eradication of places for thousands of qualified students.

${ }^{13}$ Anushka Asthana and Rachel Williams, 'Growing Outcry at Threat of Cuts in Humanities at Universities', The Observer, 28 February 2010, 9.

${ }^{14}$ For the tragically misconceived fees promise to students see 'Liberal Democrat: Policies for Students and Young People', <http://network.libdems.org.uk/ manifesto2010/libdem_manifesto_2010.pdf $>$, accessed 25 January 2010. 


\section{Bill Luckin}

towards an elite cluster of universities. Little wonder that the Russell Group couched their defence of the Browne Report and the cuts in language that emphasised the necessity of maintaining 'world class' status and neglected the plight of those lower down the pecking order. ${ }^{15}$

Fourth, every institution, but particularly those in the post-1992 group, has for some time been preparing for the new funding arrangements which come into operation in September 2012. Vice-Chancellors have no option but to be ready. Among the newest universities, this rebranding process involves a narrowing of subjects on offer and a return in many places to the status of super-polytechnic, specialising in science, technology, a broad range of vocational subjects and business and computer studies. The tragedy is that more than a handful of these universities have developed vibrant, small-scale arts and humanities programmes. ${ }^{16}$

Nearly every Vice-Chancellor would like to protect these budding centres of excellence but knows that her central duty is to mould the new academic environment in a way that will prevent an institution from being consigned to the 'failing' category or threatened by the linked dangers of private take-over or abject collapse, with the loss of several hundred rather than thirty or forty jobs. ${ }^{17}$ The cull of vulnerable arts and social science staff in the post-1992 sector began in 2009 and has increased in tempo as larger numbers of university administrators have realised that it will be impossible to cover costs in non-STEM departments at a fee of $£ 6,000$ per annum. Fifth, post1992 universities which have developed exciting interdisciplinary courses in the social sciences and humanities have been encouraged to recruit their students from postcodes dominated by socioeconomic groups - and ethnic minorities - in which only an exceptionally small percentage of parents have had experience of higher or further education. These are the locations in which potential applicants are most likely to be intimidated by the new fee arrangements. Personal and communal windows will be closed. The possibility of undertaking an undergraduate degree - and for a small minority postgraduate research - will be greatly diminished. Finally, several post-1963 institutions have already moved in the same direction as the post-1992 group. The University of Sussex has savaged early modern history and adopted a mission statement that subverts its founding fathers' determination to champion path-breaking undergraduate and research degrees that assumed the existence of close interactions between the arts, social sciences, sciences and technology. ${ }^{18}$

\footnotetext{
${ }^{15}$ See 'Russell Group Response to the Browne Review of University Funding', 10 October 2010, $<$ http://www.russell-group-latest-news/121-2010/ 4544>, accessed 3 December 2010.

${ }^{16}$ Note here, however, analogies with transfer practices between the Premier League and the lower divisions. 'Research-active' members of staff rapidly seek a position higher up the university ladder.

Similarly, talented graduates search for a postgraduate place in a Russell Group or post-1963 institution. The post-1992 sector is repeatedly robbed by the Chelseas and Manchester Uniteds of the larger system.

${ }^{17}$ Jeevan Vasagar, 'Fears Cuts will Force Swaths of Universities to Close Down', The Guardian, 19
}

October 2010, 15. The number of failing universities ear-marked for possible closure or take-over may be twenty.Confidential information from a vicechancellor to the author

${ }^{18}$ On this and other aspects of the crisis see the brilliant Anthony Grafton, 'Britain: The Disgrace of the Universities', New York Review of Books, 8 April 2010, 32. Specifically on the Sussex situation see Gabriel Josopovici, 'What are the Universities For? A Letter on the VC's

"Execrable" English', <http//www.defendsussex. wordpress.com/2010/01/07/>, accessed 25 January 2011 , 


\section{The Crisis, the Humanities and Medical History}

\section{Conclusion}

Undergraduate history places will be greatly reduced in every post-1992 university and many post-1963 institutions. Elsewhere, the discipline will survive. However, the emphasis will move even more rapidly towards recent and contemporary studies. A shift of this kind is now well established in the UK and the United States. Thus, a random survey of leading international medical historical journals over the last decade indicates that an ever-growing proportion of contributions has been focused on the twentieth and early twenty-first centuries. The same is true of doctoral theses. Under-funded government grant-giving bodies have no option but to follow the post-Thatcherite, post-Blairite demand for relevance in the service of regenerating and modernising the economy. Large non-governmental supporters of postgraduate research also follow the Zeitgeist, not least since they benefit from congenial links with national policy-makers, regardless of which party holds power. In the longer term, the shift towards the twentieth and early twentyfirst centuries will radically transform the identity and status of the history of medicine and, even more damagingly, history as a dynamically critical discipline. However, in time, strategies for renewal will emerge. But these cannot be expected to arrive, Santa Claus-style, from the beleaguered British state. Academics will have to do the thinking, the analysis and the work for themselves. ${ }^{19}$

\section{Acknowledgements}

The author would like to thank Professors Roy MacLeod and Sander Gilman for their sage and temperate comments during discussion of the spoken version of this paper. Please note that this paper was written prior to the tuition fees vote, and further protests of 9 December 2010.

\footnotetext{
${ }^{19}$ Nor should this be, as it might well be, an insular process. The reasons are provocatively set out by Martha C. Nussbaum, Not for Profit: Why
}

Democracy Needs the Humanities (Princeton: Princeton University Press, 2010). 